UN biotechnology centre

\section{India blocks site decision}

THE United Nations Industrial Development Organization (UNIDO) has moved one small step towards establishing a biotechnology research centre devoted to Third World needs. In the frequently exasperating manner of UN decisions, the centre now exists - but only on paper. At a meeting in Madrid last week, delegates from 25 nations agreed to set up the centre, but made no decision on where it should go, or who should pay for it despite strong recommendations from an expert committee and some $\$ 150$ million on offer from prospective hosts. The decision has now been referred to a new committee, which will report back to UNIDO next year.

The recommendation of the expert committee of biotechnologists from Argentina, China, Hungary, Indonesia, Nigeria, Sweden, Yugoslavia, and Ireland that the centre should go to Brussels, Trieste or Bangkok was not even formally discussed. According to one observer, the impasse was a result of high-level diplomatic pressure from India which has insisted that the centre go to New Delhi.

Most delegates, it seems, had been instructed by their governments to vote for India - but were impressed at the same time by the expert committee's rejection of the New Delhi location.

According to the expert committee, it would be bery difficult to set up a regular supply to a centre in New Delhi of fine chemicals, biochemicals, and radioisotope labelled materials which must be "obtainBrussels or Trieste.

ed on a day-to-day basis from international suppliers', The supplies would be hindered by currency and customs restrictions in India, the committee felt.

Also, said the committee, there was little genetic engineering per se in India - probably because the difficulties of working in India have made it impossible to attract and repatriate Indian genetic engineers abroad. There is good molecular biology in the country (notably in Bangalore), according to the committee, but these centres are far from New Delhi. The committee was thus concerned that a biotechnology research centre in New Delhi would suffer from isolation. These conditions did not apply in Bangkok, they said, and even less in

However, India argues that the right environment could be supplied in New Delhi; that their expatriate experts would come back if the centre was established in India; and that if the centre were in a developed country it would suffer from a different kind of isolation: academicism, and isolation from Third World needs.

In Madrid, the compromise and temporary solution was to "establish" the centre but hold no vote. The past expert committee was non-governmental, and to that extent apolitical and unbiassed. The new committee to advise on siting will be governmental. As a result the UNIDO biotechnology centre is likely to be even more politically exposed than before.

Robert Walgate

\title{
India's bait for expatriates
}

\section{New Delhi}

THE continuing efforts of the Indian Government to encourage expatriate scientists and doctors to return home seem to have backfired. Far from being pleased to welcome back their colleages, scientists that stayed at home are complaining that those responsible for the "brain drain" are being promised better treatment than those who loyally resisted the temptations of high salaries in the United States and elsewhere.

Prime Minister Indira Gandhi announced the latest proposals last month the government intends to set up a new "technology city" where Indian scientists now working abroad would be able to work in the sort of conditions that they have become used to. Research areas for the town would be in "frontier sciences" such as space, fibre optics and lasers, and the cost of the project is estimated at US \$125 million for the infrastructure and first class laboratory equipment.

The government has been trying for some years to stem the flow of highly qualified scientists and technical personnel to the developed countries. A study by the United Nations Conference on Trade and
Development estimated that India loses the equivalent of US\$17,200 in education costs for every scientist leaving the country and US $\$ 33,000$ for every doctor.

So far attempts to reverse the trend have met with little success. The United Nationsfinanced TOKTEN programme (for Transfer of Knowhow Through the Expatriate Nationals), which is intended to bring back expatriates for brief periods of a few months, has also evoked little response. Mrs Gandhi seems to be hoping that the technology city will help bridge the gap.

Plans for the city have not yet been finalized but initial reactions have been hostile. Professor M.V. Hariharan, dean of research and development at Bombay Indian Institute of Technology, says that top scientists in India whose sense of commitment leads them to stay despite poor research facilities would be penalized. "Why not build a science city for them?" he asks. Others point out that by "pampering" returning scientists the government runs the risk of creating two classes of scientists working in the same field - one privileged and one making do with second best.
Soviet science teaching

New moves for more scientists

SOVIET universities and technical schools have had to lower their admission requirements in order to fill the less popular courses, the Minister of Higher and Special Secondary Education, Dr Vyacheslav Elyutin, has admitted. Although all this year's one million university places were eventually filled, this was achieved only after reducing the entrance examination average mark from 4.5 (on a 5-point scale) to 4 , and "much vocational guidance" of the applicants.

Although the minister did not say which were the less popular courses, according to the rector of the Moscow Energy Institute, Dr Valentin Grigor'ev, the shortfall in science and technology applications is "alarming" - over the past decade, there has been a 20 per cent drop in applications. Much of the blame, Dr Grigor'ev suggests, lies with "incorrectly organized" vocational guidance in schools, which fails to overcome "materialist attitudes" in the young people's home and school background.

There is a general feeling that the pure sciences carry more prestige than applied, but there have been no suggestions that material gains are less for technologists than for academics. By "materialist attitudes" Dr Grigor'ev may have been referring to the problems arising from the rule that Soviet graduates have to work for three years in a post assigned to them, which can be anywhere in the Soviet Union. Engineers and technical specialists are all too likely to be sent to the remoter areas of Siberia and the Far North, where conditions are primitive. During the past few years, there have been frequent complaints that too many new graduates are claiming exemption on health or compassionate grounds from taking up appointments in remote areas, while some manage to "disappear" each year, in spite of the strict system of internal passports.

New planning procedures are therefore being introduced to ensure the necessary supply of technical graduates not only in absolute numbers but also in the right places. In the developing regions of Siberia, the Far North and the Far East, admissions to local universities and colleges have been increased, while universities in the European regions of the Soviet Union are sometimes taking "special admissions" from the developing regions, on the understanding that the young people so trained will return home when they graduate.

At the same time, new science curricula have been introduced throughout the Soviet Union, with a greater emphasis on "foundation" theoretical training, less fragmentation of courses and, in particular, the integration of mathematics into the general syllabus.

Vera Rich 